\section{The Unlikely Union of Same-Sex Marriage, Polygamy and the Charter in Court}

\section{Matthew Hennigar}

For several years now, I have been doing work on litigation surrounding same-sex marriage (SSM), and when I present my research (both at conferences and informally over drinks), I am almost invariably asked how court decisions legalizing $\mathrm{SSM}^{1}$ will affect the laws against polygamy. As a recent article in the Toronto Star observed, ${ }^{2}$ gay marriage is often seen as a "slippery slope" to polygamy; some argue that it opens the jurisprudential door to other fundamental challenges to the traditional, monogamous definition of marriage. ${ }^{3}$ For example, it is true that the Supreme Court of Canada decisively rejected the government's argument in the SSM cases that the Canadian Charter of Rights and Freedoms ${ }^{4}$ was not intended to revolutionize fundamental social institutions. Recent developments in British Columbia appear likely to put this contention to the test.

For over six decades, a fundamentalist sect of the Mormon Church has been practicing polygamy in the insular community of Bountiful, British Columbia, which now boasts a population of roughly 1,000 . This practice has been permitted by successive provincial governments of all partisan stripes, despite the fact that section 293 of the Criminal Code 5 unequivocally prohibits polygamy. In recent years, the B.C. government has been advised by its own Ministry of Attorney General, and most recently by a special prosecutor assigned to the issue, that prosecution - and the ban on polygamy itselfwould probably not survive a freedom of religion claim under the Charter. The special prose- cutor, Richard Peck, recommended instead that the government seek legal guidance by referring the constitutionality of section 293 to the B.C. Court of Appeal (with an appeal to the Supreme Court likely). On 1 August 2007, B.C. Attorney General Wally Oppal-who has gone on record with the view that polygamy is demeaning to women and unacceptable-indicated that his government would follow Peck's advice and refer the matter to the B.C. Court of Appeal. While Oppal has subsequently requested yet another opinion from his ministry on whether charges could be laid under a "more aggressive approach," it seems increasingly likely that the constitutionality of Canada's anti-polygamy law will soon be before the courts.

The purpose of this article is to canvass the legal issues such a case will raise based on current Charter jurisprudence. ${ }^{6}$ The analysis will reveal two key points: first, and contrary to some conservative commentary, the recent decisions legalizing SSM do not ultimately benefit polygamists; and second, despite this, the courts will have a difficult time upholding the ban unless they embrace feminist critiques of polygamy. In this article I quickly summarize the key decisions on SSM, provide a short backgrounder on Bountiful and the practice of polygamy, and then conclude with the analysis of Charter issues raised by polygamy, including equality rights, freedom of religion, and liberty. It should be stressed, however, that while the situation in Bountiful is the one most likely to bring the polygamy issue to the courts and is 
my focus here, any ruling will have implications far beyond this small community in rural B.C. Polygamy is advocated (and quietly practiced in Canada) by some ultra-Orthodox Jews and Muslims, and the latter group is of particular relevance as Canada continues to accept more immigrants and refugees from Muslim countries where Islamic Sharia law accepts the practice. In short, in addition to raising the issues of religious freedom and the equality rights of religious minorities, polygamy may present a clash between multiculturalism-recognized in section 27 of the Charter - and Canadian criminal law, as well as sexual equality as enshrined in sections 15 and 28 of the Charter.

\section{The Same-Sex Marriage Rulings}

With their respective rulings in EGALE and Halpern in the spring of 2003, the Courts of Appeal in B.C. and Ontario became the highestranked courts in the country to conclude that gay and lesbian couples have a constitutional right to be married in law. Some churches, most notably the Metropolitan Community Church of Toronto, had already performed purely religious marriage ceremonies for members of its congregation. The courts' decisions meant that these would now be legally recognized, and that civil marriage ceremonies would now be open to same-sex couples. The cases turned primarily on the claim that gays and lesbians' equality rights in section 15 of the Charter were violated by the common-law definition of marriage. Although the institution of monogamous heterosexual marriage had existed for several centuries in the Anglo-American context, the common-law definition, as of Spring 2003, dated back to the 1866 British case Hyde v. Hyde and Woodmansee: "marriage, as understood in Christendom, may for this purpose be defined as the voluntary union for life of one man and one woman, to the exclusion of all others."

Following Law v. Canada, ${ }^{8}$ a successful equality rights claim has to answer all of the following questions in the affirmative:

A. Does the impugned law (a) draw a formal distinction between the claimant and others on the basis of one or more personal characteristics, or (b) fail to take into account the claimant's already disadvantaged position within Canadian society resulting in substantively differential treatment between the claimant and others on the basis of one or more personal characteristics?

B. Is the claimant subject to differential treatment based on one or more enumerated and analogous grounds?

C. Does the differential treatment discriminate, by imposing a burden upon or withholding a benefit from the claimant in a manner which reflects the stereotypical application of presumed group or personal characteristics, or which otherwise has the effect of perpetuating or promoting the view that the individual is less capable or worthy of recognition or value as a human being or as a member of Canadian society, equally deserving of concern, respect, and consideration?

Framed in these terms, the courts readily conceded that the common law-definition of marriage discriminated against gays and lesbians. The law clearly distinguished same-sex couples from heterosexual ones, and denied homosexual unions the legal benefits of marriage (and associated protections, when those unions dissolve). While the wording of section 15 does not specify protection for sexual orientation, the Supreme Court used the section's open wording to recognize it as an "analogous ground" deserving protection in the 1995 Egan v. Canada decision. ${ }^{9}$ As recognized in Egan, gays and lesbians make up a historically disadvantaged group which has long suffered under deep-seated discriminatory attitudes in Canadian society. These attitudes were manifested in the criminal law (in particular in the prohibition on "sodomy"); in discriminatory treatment by employers and landlords; and, of course, in the body of family law relating to marriage, spousal support, custody, adoption and next-ofkin relations. On the question of whether barring same-sex marriage is based on discriminatory stereotypes of gays and lesbians, the courts were unequivocal:

\footnotetext{
Same-sex couples are capable of forming
} 
"long, lasting, loving and intimate relationships." Denying same-sex couples the right to marry perpetuates the contrary view, namely, that same-sex couples are not capable of forming loving and lasting relationships, and thus same-sex relationships are not worthy of the same respect and recognition as opposite-sex relationships. ${ }^{10}$

Finally, the courts found the exclusion simply unnecessary, rejecting the federal government's argument that "The concept of marriage-across time, societies and legal cultures-is that of an institution to facilitate, shelter and nurture the unique union of a man and woman who, together, have the possibility to bear children from their relationship and shelter them within it." 11 As even the Attorney General of Canada acknowledged, procreation and child rearing are not the only purposes of marriage-others include intimacy, companionship, societal recognition, economic benefits, and the blending of two families - and both the Ontario and B.C. courts observed that same-sex couples can choose to have children through adoption, surrogacy, and donor insemination. Conversely, heterosexual married couples are not required to have children.

For essentially the same reasons, the courts ruled that the government failed to demonstrate that the violation was justified under section 1 of the Charter, which permits "reasonable limits" to be imposed on Charter rights:

The Canadian Charter of Rights and Freedoms guarantees the rights and freedoms set out in it subject only to such reasonable limits prescribed by law as can be demonstrably justified in a free and democratic society.

Following the formulation laid down in $R$. v. Oakes,${ }^{12}$ the government must show that the violation of a right is for a "pressing and substantial objective" using "proportional" means, where the latter requires demonstrating that a "rational connection" exists between the objective and the means used, that the "reasonably least restrictive means" were used ("minimal impairment"), and that the collective benefit of the objective outweighs the cost to the individual whose rights have been violated. The courts found that the government failed to make its case on all counts. Even allowing the objectives of promoting procreation and child rearing, preventing same-sex marriage does nothing to encourage reproduction by heterosexual couples, and an increasing number of same-sex couples are having and raising children. Moreover, the law completely excluded same-sex couples from a fundamental societal institution, and "complete exclusion cannot constitute minimal impairment." 13 Absent a justifiable rationale for prohibiting SSM, the courts lifted the ban.

Notably, in Halpern, the pro-SSM Metropolitan Community Church of Toronto (MCCT) made the additional argument that denying the Church the right to perform legally recognized marriages violated its freedom of religion under section 2(a) of the Charter. This claim proved unsuccessful. The Ontario Court of Appeal's view was that although "marriage is a legal institution, as well as a religious and a social institution," the SSM case was "solely about the legal institution of marriage. It is not about the religious validity or invalidity of various forms of marriage. We do not view this case as, in any way, dealing or interfering with the religious institution of marriage." 14 In short, because the MCCT could perform religious marriage ceremonies for gays and lesbians-even if they were not legally recognized-the Church's religious freedom was not violated. Conversely, and as confirmed by the Supreme Court in the subsequent Reference re Same-Sex Marriage, ${ }^{15}$ the Charter's protection of freedom of religion means that churches that are doctrinally opposed to homosexuality cannot be forced to perform or recognize SSMs.

What, then, are the implications of these findings for polygamists?

\section{Polygamy: Some Background}

The practice of polygamous or plural marriage in Bountiful is based on a literalist reading of the Old Testament, which features many examples of men taking multiple wives, and on Mormon founder Joseph Smith, Jr.'s revelation that only men with three or more wives can reach the highest realm of heaven. (Sect members also believe that the "prophet" or church 
elders should determine which man a woman will marry). This raises a matter of terminology, as what is practiced by residents of Bountiful-as with most other practitioners of plural marriage, including some ultra-Orthodox Jews and some Muslims under Sharia law-is more accurately labelled polygyny, or taking multiple wives, since all of the plural marriages involve a single man with multiple wives, rather than the reverse (polyandry) or a mix of many men and women (polygamy, in its strict usage). However, for simplicity, I will use the more familiar term "polygamy" throughout to refer to all of these permutations. Polygamy has been illegal in Canada since before Confederation, first under British common law (Hyde v. Hyde and Woodmansee) and then in our first Criminal Code, adopted in 1892. The current prohibition is found in section 293 of the Criminal Code, and reads as follows:

293. (1) Every one who

(a) practises or enters into or in any manner agrees or consents to practise or enter into

(i) any form of polygamy, or

(ii) any kind of conjugal union with more than one person at the same time, whether or not it is by law recognized as a binding form of marriage, or

(b) celebrates, assists or is a party to a rite, ceremony, contract or consent that purports to sanction a relationship mentioned in subparagraph (a)(i) or (ii),

is guilty of an indictable offence and liable to imprisonment for a term not exceeding five years.

Prosecutions under section 293, however, are rare.

\section{Polygamy and the Charter in Court}

\section{Equality Rights}

If SSM is supposed to be a slippery slope to polygamy, it stands to reason that our analysis should begin with equality rights, which formed the basis of the successful claims in EGALE and Halpern. How well would those precedents serve the residents of Bountiful?

The short answer is not particularly well. That is not to say that polygamists cannot successfully claim protection under section 15 , but as I will explain, the claim rests on grounds that have nothing to do with gays and lesbians. Recalling the standards established in Law, polygamists actually have a fairly strong claim that section 293 of the Criminal Code discriminates against them. Section 293 certainly makes a distinction between polygamy and other forms of marriage by criminalizing the former, and does so on the basis of a "personal characteristic," in this case marital status. Moreover, while section 293 does not mention religion, it nonetheless treats the religious community of Bountiful (and of polygamous Muslims and Jews) differently from religious groups which practice monogamy.

Similarly, as to the question of whether this differential treatment is based on one or more enumerated and analogous grounds, there are at least two different grounds upon which polygamists could answer in the affirmative (neither of which is sexual orientation). The first is the enumerated ground of religion, which to date has never been successfully claimed in the Supreme Court of Canada. This does not preclude success, however, as previous claims of religious equality failed in cases where the law had been enacted before section 15 came into effect, ${ }^{16}$ or where the claim was trumped by the right to denominational schooling enshrined in section 93 of the Constitution Act, $1867 .{ }^{17}$ There is a chance the Court could rule that polygamists are being discriminated against not because of their religion but because of a particular practice, but this seems unlikely as the very basis for this sect's schism from the larger Mormon Church was its position on polygamy. 
A second potential ground is "marital status," which was accepted as an analogous ground in Miron v. Trude ${ }^{18}$ and Nova Scotia (Attorney General) v. Walsh. ${ }^{19}$ Although it is likely that a court would simply accept an argument that the precedent regarding marital status as an analogous ground applies to polygamy, it is worth noting that there are some significant differences between these cases and polygamy. Miron and Walsh arose because of differences in the way the law treated unmarried but monogamous common-law spouses as compared to married couples. In Walsh, the court upheld the distinction that common-law spouses do not automatically receive half of any "matrimonial" property in case of separation. As well, these marital status cases concerned civil law (provincial car insurance in Miron, family law in Walsh), while polygamy arises in the context of criminal law.

Finally, regarding the issue of whether section 293 offends the human dignity of polygamists as required by the third prong of the section 15 test laid down in Law v. Canada, polygamy is viewed with moral opprobrium by the majority of society, which is the reason it was criminalized in the first place. There is no doubt that this prevailing attitude, and its embodiment in the Criminal Code suggests that polygamists are "less capable or less worthy of recognition or value as human beings or as members of Canadian society, equally deserving of concern, respect, and consideration" pursuant to part three of the Law test. As such, section 293 clearly violates the dignity of polygamists in the terms laid down in Law.

Before proceeding, it is interesting to compare the polygamists' section 15 claim with that of recreational pot smokers, whom the Supreme Court rejected as an analogous ground in $R$. $v$. Malmo-Levine and R. v. Caine.$^{20}$ Let us assume for the moment that both the drug users and polygamists are guilty of what Herbert Packer termed consensual or "victimless crimes," in which their actions cause no harm to others. ${ }^{21}$ Both groups have seen their behaviour prohibited based on the majority's moral values, ${ }^{22}$ but absent the precedents in Miron and Walsh, would the marital status of polygamists qualify as an analogous ground? If we bracket out the religious basis for polygamy, what remains is an equality rights claim based on a socially derided and criminalized but ultimately voluntary actplural marriage-rather than an immutable characteristic which is irrelevant to the law in question. This strikes me as extremely similar to the argument advanced unsuccessfully by the pot smokers in Malmo-Levine. As such, the real issue for polygamy in the context of section 15 should be religious discrimination (and, just for fun, we can make another analogy to drug use: if the colonists in Bountiful can make an equality rights claim to polygamy based on religion, why can Rastafarians not make an equality rights claim to possess and smoke marijuana based on its centrality to their religious practices? Just a thought).

All of this is to say that polygamists would probably be able to establish a prima facie violation of their equality rights. Their claim would still need to survive a section 1 reasonable limits analysis, which I take up after considering a Charter claim based on freedom of religion.

\section{Freedom of Religion}

As polygamy in Bountiful is based on religious beliefs, the most obvious constitutional challenge would be based on the Charter's section 2(a) "freedom of conscience and religion." To begin, the claimants would need to show that polygamy is essential to their religious beliefs. It is unlikely that the courts, which have taken a "broad, purposive approach" to the prime facie scope of rights, would reject this claim. While the mainstream Mormon Church, under threat of prosecution in the U.S., officially disavowed Joseph Smith's position on polygamy in 1890, the group in Bountiful (among others) broke away largely because of this issue. The group also has textual support from the Bible and past practice, as monogamy was only adopted in Christendom because of Roman influence, and other religions with roots in the Old Testament-including some Jews and Muslims, and other Mormons-practiced or still practice polygamy.

As such, polygamists are likely to have more 
success at this stage than the Metropolitan Community Church had in Halpern. In large measure this is because the courts do not have the same "out" here of allowing purely religious ceremonies, as even exclusively religious plural marriage is prohibited. Recall the Criminal Code's section 293(1)(a)(ii), mentioned above, which prohibits "any kind of conjugal union with more than one person at the same time, whether or not it is by law recognized as a binding form of marriage" [emphasis added]. Notably, if one tried to argue in defence of polygamy that the second and subsequent unions were not "conjugal" - that is, they were celibate-section 293(2) makes it clear that it is not necessary "to prove that the persons who are alleged to have entered into the relationship had or intended to have sexual intercourse." In any case, this is hardly an issue in Bountiful, where one of the community's leaders, Winston Blackmore, has over 100 children by his 30 wives.

Assuming that polygamists clear this initial legal hurdle, they would still need to address the Court's well-established position that the freedom to hold religious beliefs is distinct from the right to act on those beliefs. On its face, it is hard to see how such a distinction could be made in this case; it seems unintelligible to suggest that religious freedom protects the right to believe in polygamy but not to practice it. The closest parallels, in which religious belief required a particular course of action contrary to state regulations, are the blood transfusion ${ }^{23}$ and child custody cases ${ }^{24}$ involving Jehovah's Witnesses. These cases hold some important lessons for polygamists. First, in all of these cases the Supreme Court considered whether countervailing principles-the "harm" principle, or the "best interests of the child"-provide internal limits to the freedom to act upon religious belief. In other words, echoing John Stuart Mill's classic formulation in On Liberty, ${ }^{25}$ the Court asked whether one's enjoyment of a right extends only to the point where it interferes with the ability of others to do the same? If so, and if such interference could be shown, then there would be no prima facie rights violation, and so there would be no need to engage in a section 1 "reasonable lim- its" analysis-in short, the prima facie right to act upon a religious belief would be narrower than the right to hold that belief. However, in each case a majority of the Court (albeit narrowly) refused to employ this approach, opting instead to read the right broadly, in keeping with the Court's "living tree" philosophy, and work out the conflicting principles in the context of section 1 .

A second lesson from the transfusion and custody cases is that the Court uses this approach of interpreting rights broadly and handling limitations of those rights under section 1 , even if the case involves adults making decisions affecting minors, which is the case with respect to polygamy. Children have no control over whether they are born into polygamous families, with all the negative consequences that that may entail. These consequences include, according to studies commissioned by Status of Women Canada and the Department of Justice Canada ${ }^{26}$ : the unclear legal status of children of illegal marriages (which affects inheritance, custody, support payments, etc.), possible psychological damage, economic deprivation, lower levels of academic achievement and self-esteem and, in the case of Bountiful, probably sexual abuse. So, even though there are competing principles at play here (more about these below), the Court's track record suggests that it would not block the rights claim at this stage.

As such, the case law suggests that the residents of Bountiful would meet their burden of showing a prima facie violation of religious freedom, thus putting the onus on the government to demonstrate why limiting their religious freedom is reasonable under section 1 . As the government's argument could be virtually identical to that offered for a violation of equality rights, a single analysis of section 1 issues will suffice.

\section{Reasonable Limits under Section 1}

\section{Limit "Prescribed by Law"}

The first step in section 1 analysis requires verifying that the rights violation is "prescribed 
by law." This is self-evident here, as it is a provision of the Criminal Code which is at issue with respect to polygamy.

\section{Pressing and substantial objective}

Although the origin of the anti-polygamy law is rooted in enforcing mainstream JudeoChristian morality through the criminal law, this is typically no longer a legitimate objective in the eyes of the courts, given Canada's multicultural and liberal democratic character. This is evident in cases concerning pornography ${ }^{27}$ and "swingers" clubs, ${ }^{28}$ which ruled out traditional morality-based justifications for the crimes of, respectively, obscenity and indecency, in favour of a "harm-based" approach. A majority of the Supreme Court in Malmo-Levine maintained that morality could be the legitimate basis of criminal law in narrow circumstances, when it reflects societal values "beyond the simply prurient and prudish" rather than "conventional standards of propriety" or current tastes. ${ }^{29}$ Justices Gonthier and Binnie, writing for the majority, identified bestiality, cannibalism and consensual dueling as examples-but not, notably, polygamy. Moreover, as noted, polygamy today is not universally condemned among the cultural communities within Canada, nor is it without historical precedent. As such, it is unlikely that a strictly morality-based objective for the prohibition would be accepted by the Court. What, then, would be a liberal, harm-based objective for prohibiting polygamy? The Court would have several to choose from, but all are somewhat problematic:

1. Protecting underage girls from forced marriage and sexual exploitation. This argument might be confounded somewhat by the government's inability to prosecute successfully any actual cases, even after appointing a special prosecutor to investigate the issue. Moreover, polygamy does not necessarily involve young girls, and minors could arguably be protected in other ways, such as by prosecuting the offences of underage marriage, sexual abuse, and/or other sexual offences (sexual exploitation, sexual interference, etc.). On the other hand, relying on individual prosecutions misses the bigger picture, which is the highly indoctrinating context in which these youths live. As a report for Status of Women Canada by the Alberta Civil Liberties Research Centre observes, ${ }^{30}$ the children of Bountiful are indoctrinated against discussing any sexual abuse they experience, and indeed, are discouraged from even recognizing it as abuse as it is framed as obedience to their leaders who are God's prophets on Earth. Prosecution of sexual offenses without the assistance of the victim is extremely difficult, and virtually impossible if the victim and their family actively frustrate the Crown's efforts.

2. Child protection more generally, based on the factors cited above (uncertainty over their legal status, economic deprivation, psychological harm, etc.).

It should be noted at this point that if either or both of these objectives for the prohibition of polygamy are the only objective(s) the Court accepts, it opens the door a crack to polygamists who do not have children (elderly couples, for example). However, it is unlikely that such a narrow concern would prevent the Court from upholding the ban in its entirety.

3. Promoting sexual equality. In their study for the Department of Justice, Rebecca Cook and Lisa Kelly ${ }^{31}$ lay out several ways in which polygamy, as practiced in Bountiful and elsewhere in the world, harms women and undermines sexual equality. These include:

- as a form of patriarchy, polygamy is intended to control women and prevent wives from asserting their interests and rights within marriage;

- denying couples sexual intimacy, which "hinders the equal sharing of both material and emotional attention";

- fostering competition between wives (although examples of close co-operation also exist) and unequal distribution of domestic resources; 
- elevating levels of mental illness and stress among wives;

- aggravating deprivation and poverty;

- undermining women's enjoyment of citizenship (including fundamental political values such as freedom of expression, freedom of assembly and association, the right to freedom of thought, belief and opinion, and even the right to vote); and

- as a consequence of unequal power relations based on gender, women and adolescent girls are often unable to refuse sex or insist on safe and responsible sex practices, exposing them to unsafe pregnancies, STDs and HIV/AIDS.

These factors might carry particular weight in the context of a violation of polygamists' equality rights, since it could be argued that allowing polygamy offends the Charter's section 15 guarantee of sexual equality, as well as parallel guarantees in human rights legislation and international treaties to which Canada is a ratified signatory. The objective of promoting sexual equality would certainly allow a comprehensive ban on polygamy, but it does raise one major concern: banning polygamy based on the harm it does to women represents a fairly invasive form of statist paternalism, as it denies the agency of those women who nevertheless want to participate in plural marriage. This concern is arguably attenuated by the fact that polygamy typically occurs in an extremely insular and indoctrinating context, which serves to constrain or deny women's agency in the first place.

4. Preventing in-breeding. While this is a concern in highly insular communities like Bountiful, it is not inherent to plural marriage. This said, the Nova Scotia Court of Appeal's decision upholding the Criminal Code's ban on consensual incest (section 155) in R. v. F. (R.P.) $)^{32}$ cited "the societal goal of reducing the chance of children being born with genetic mutations."

Notwithstanding the concerns I have raised, it seems likely that the Court would accept the government's claim that the ban on polygamy has a pressing and substantial objective, particularly since the courts usually defer to the government at this stage of analysis. Moreover, in Malmo-Levine, the Court characterized the burden of proof on government to show a threat to vulnerable groups (or health) in the context of section 1's "pressing and substantial objective" analysis as "minimal." In other words, the government should not have a particularly hard time satisfying this requirement in the polygamy case. What, then, is the Court likely to decide about the ban's proportionality?

\section{Proportionality}

i) Is there a rational connection? While this is highly speculative without knowing what objective the Court might accept, it does stand to reason that if Parliament believes polygamy is the root of the problem, then banning polygamy is a "rationally-connected" response.

ii) Is the impairment minimal? As is usual in section 1 analysis, this is likely to be the biggest obstacle for the government, especially since there are ample precedents of the Court objecting to "total" prohibitions where more tailored ones might suffice (take for example the cases regarding Quebec's sign law ${ }^{33}$ and tobacco advertising ${ }^{34}$ ). While it is true that a similar argument was employed in the SSM cases, the situation is subtly different from the ban on polygamy. In EGALE and Halpern, the courts argued that the "complete exclusion [of homosexuals from the institution of marriage] cannot constitute minimal impairment." 35 Polygamists, in contrast, are not being completely excluded from the institution of marriage, but being told to limit their involvement in that institution to only one partner at a time. The minimal impairment analysis would also be the real test of the Court's ability to reconcile religious freedom with sexual equality (and/or child protection), or whether the former must simply give way to the latter, in which case a total ban would be upheld. How the Court resolves this ques- 
tion has direct consequences for any potential remedy, as will be discussed below.

iii) Does the collective benefit outweigh the individual cost? Banning polygamy has some benefits for the non-polygamous majority, but they are mostly of the economic variety (imagine, for example, if Blackmore was able to claim Canada Child Tax Benefits for all 100 of his children). The more pressing issue to the Court would be the presence of any benefits that accrue to the children of polygamous marriages, as they cannot speak for themselves, and are too young to have formed their own opinions about their religious beliefs. On this count, the Court would have sufficient grounds to find in the government's favour.

\section{Remedy}

If we were to assume for a moment that the Court did not find a complete ban on polygamy to be a reasonable limit on religious freedom, this rights violation would be the easiest one to remedy, according to Martha Bailey et al. ${ }^{36}$ All the Court would need to do to satisfy religious freedom is read out of the Criminal Code the phrase in section 293(1)(a)(ii) prohibiting polygamy "whether or not it is by law recognized as a binding form of marriage," thus allowing purely religious ceremonies which have no status in law-indeed this is what the Court said was sufficient to satisfy the religious freedom of the pro-SSM Metropolitan Community Church in Halpern. This would also side-step the government's likely argument that legalizing polygamy would wreak havoc on Canadian family law and government programs, all of which are premised on the model of the monogamous (or single-parent) family. A successful claim under section 15 , however, would require a more substantial remedy than for a violation of section 2(a), and entail nullifying at least some part of section 293 of the Criminal Code, though the grounds claimed under section 15 (religion versus marital status) would be relevant here. A ruling based on religious discrimination could allow the courts, or a government in response to the ruling, to carve out an extremely narrow exception for well-established religious com- munities, in part to prevent any secular opportunists from trying to rack up spousal pension benefits or RRSP room. A decision based on marital status, on the other hand, would require an even broader remedy, most likely the complete invalidation (either immediate or delayed) of section 293. Notably, this might create favourable conditions for the government to invoke the notwithstanding clause, as it would likely face fairly little public backlash for retaining the prohibition on polygamy.

\section{Right to Life, Liberty and Security of the Person}

Before closing, I should note that some arguments against the ban on polygamy could arise from the Charter's section 7 right to liberty, which the court has expanded beyond its initial "freedom from physical restraint" to include government interference with a person's "fundamental personal choices." ${ }^{37}$ As Bailey et al. aver, "it is difficult to conceive of a more fundamental personal choice than whom one chooses to marry." ${ }^{38}$ Be that as it may, section 7's wording indicates that the rights in that section may be limited when doing so is "in accordance with the principles of fundamental justice." The Charter does not specify these principles, and the Court has tended to focus on what does not satisfy fundamental justice. The latter includes vagueness in the law, lack of "fair notice" for those subject to a law, and arbitrary application of the law (i.e., too much discretion left to government officials, especially if there is evidence of bias). The ban on polygamy suffers from none of these defects. Anyone practicing polygamy is perfectly aware that they are violating the Criminal Code, and "polygamy" is clearly defined as the taking of more than one spouse at a time, even if in a purely religious ceremony. While there is obviously discretion involved in deciding whether to prosecute, this is no different from the discretion Crown Attorneys have over prosecuting any offence-moreover, the Court has ruled that this discretion is itself constitutionally protected except in cases of "flagrant impropriety." 39 On the other hand, the promotion of sexual equality and the protection of children are surely consistent with the prin- 
ciples of fundamental justice. Thus, the same concerns which would justify limiting religious freedom in the context of section 1 would also justify internally limiting section 7 , so a claim advanced under section 7 would face the same calculus of success as a claim under sections 2(a) and 15. Having said this, a successful claim under section 7 would require the same sort of substantial remedy as required by a section 15 claim based on marital status. This suggests that it would be inappropriate for the Court to cease their analysis of other rights claims if they were to uphold the more narrowly remediable religious freedom or religious discrimination claims (which is the practice of many judges when facing multiple legal questions).

\section{Summing Up}

The foregoing analysis suggests that while polygamists have strong prima facie claims under multiple Charter rights, there are ample justifications available to the courts to rule any violations reasonable under section 1 . The most compelling of these come from feminist analyses of polygamy as an inherently sexist institution with important negative consequences for female family members, and youths in particular. In reviewing the array of constitutional principles and precedents which may support a claim by polygamists, however, one fact is clear: none of these arguments are directly derived from the same-sex marriage cases. Contrary to the Chicken Little-esque claims of some commentators, the most likely claims by polygamists are based on religious freedom, liberty (since they face criminal sanction), or their own unique experience as social outcasts. What is more, consider how the courts characterized marriage in the SSM cases: they explicitly endorsed the idea that marriage, even same-sex marriage, is a committed long-term relationship between two people, based on monogamous sexual relations, love, and mutual care. The judges also severed procreation from the legal construct of marriage, whereas polygamists typically view procreation as the central purpose of marriage, and the imperative of producing as many children as is feasible provides the main rationale for taking multiple wives. The most that can be said to link polygamy and SSM is that the samesex marriage cases illustrated that marriage, as a state-defined and supported institution, is subject to judicial review under the Charter, and that that definition cannot be grounded in mainstream Judeo-Christian religious doctrine or morality. However, the fate of polygamy in court is in no way wed (pardon the pun) to that of same-sex marriage.

\section{Notes}

* Matthew Hennigar, Department of Political Science, Brock University.

1 See, e.g., EGALE Canada Inc. v. Canada (Attorney General), 2003 BCCA 251, (sub. nom. Barbeau v. British Columbia (Attorney General), 2003225 D.L.R. (4th) 472 (CanLII) [EGALE] and Halpern v. Canada (Attorney General), [2003] 65 O.R. (3d) 161 (C.A.) (CanLII) [Halpern]. Courts in most other provinces subsequently recognized a right to same-sex marriage as well. The Supreme Court opinion in the Reference re SameSex Marriage, 2004 SCC 79, [2004] 3 S.C.R. 698 (CanLII) [Reference] refused to address whether the common-law definition of marriage violated the Charter.

2 Stephanie Levitz, "Same-sex legal argument won't hold for polygamy" Toronto Star (3 August 2007) A23.

3 See, e.g., Stanley Kurtz, "Beyond gay marriage" 8 (45) The Weekly Standard (4 August 2003), Charles Krauthammer, "Pandora and polygamy" The Washington Post (17 March 2006) A19, and REAL Women of Canada, "Address." (Submission to the Standing Committee on Justice and Human Rights on same-sex marriage, 12 February 2003), online: <http://www.realwomenca. com/newsletter/2003_mar_apr/article_3.html >.

4 Being Schedule B to the Canada Act 1982 (U.K.), 1982, c. 11 [Charter].

5 Criminal Code, R.S.C. 1985, C. C-46, s. 293.

6 In the interests of full disclosure, I should stress at this point that I am not a lawyer by training but a political scientist. Nonetheless, my teaching and research over the past decade have focused on Charter jurisprudence and argumentation, with particular emphasis on the decisions of the Supreme Court of Canada and factums submitted to that Court by the Government of Canada.

7 Hyde v. Hyde and Woodmansee, (1866) L.R. 1 P.\&D. 130, at para. 133. There was no statutory definition of marriage in Canada which excluded 
same-sex unions until 2000 (see Modernization of Benefits and Obligations Act, S.C. 2000, c.12, s.1.1, and Federal Law-Civil Law Harmonization Act No. 1, S.C. 2001, c. 4, s. 5), as the common law definition was widely taken for granted, and sodomy was still a crime until 1969. The statutory measures adopted in 2000 and 2001 were not at issue in either case.

8 Law v. Canada (Minister of Employment and Immigration), [1999] 1 S.C.R. 497 at para. 39 (CanLII) [Law].

9 Egan v. Canada, [1995] 2 S.C.R. 513 (CanLII) [Egan]. Criticism of the Court's expansive approach to s. 15 tends to ignore this basic fact about the section's wording, which reads: "Every individual is equal before and under the law and has the right to the equal protection and equal benefit of the law without discrimination and, in particular, without discrimination based on race, national or ethnic origin, colour, religion, sex, age or mental or physical disability" [emphasis added]. It is quite clear that this phrasing does not restrict equality rights to the grounds enumerated at the end of the section.

10 Halpern, supra note 1 at para. 94.

11 Ibid. at para. 89.

12 R. v. Oakes, [1986] 1 S.C.R. 103 (CanLII).

13 Halpern, supra note 1 at para. 139.

14 Ibid. at para. 53.

15 Reference, supra note 1.

16 R. v. Edwards Books and Art Ltd., [1986] 2 S.C.R. 713 (CanLII).

17 Constitution Act, 1867 (U.K.), 30 \& 31 Vict., c. 3, reprinted in R.S.C. 1985, App. II, No. 5.

Reference re Bill 30, An act to Amend the Education Act (Ont.), [1987] 1 S.C.R. 1148 (CanLII). Adler v. Ontario, [1996] 3 S.C.R. 609 (CanLII) [Adler]. While one constitutional provision does not usually "trump" or outrank another, the framers of the Charter anticipated this particular conflict and added s. 29, which explicitly protects denominational schooling from Charter challenges. In light of this, I have always found it curious that the courts agreed to hear the challenge in Adler at all (as a reference, the Court was obliged to hear the earlier case).

18 Miron v. Trudel, [1995] 2 S.C.R. 418 (CanLII) [Miron].

19 Nova Scotia (Attorney General) v. Walsh, [2002] 4 S.C.R. 325 (CanLII) [Walsh].

20 R. v. Malmo-Levine; R. v. Caine, 2003 SCC 74, [2003] 3 S.C.R. 571 (CanLII) [Malmo-Levine].

21 Herbert Packer, "Two Models of the Criminal Process” (1964) 113 University of Pennsylvania Law Review 1 at 4.
22 Although one might argue that marijuana was prohibited for some other reason, such as health protection, the historical evidence suggests otherwise. See, for example, Catherine Carstairs, Jailed for Possession: Illegal Drug Use, Regulation and Power in Canada, 1920-1961 (Toronto: University of Toronto Press, 2006) and Marcel Martel, Not This Time: Canadians, Public Policy, and the Marijuana Question, 1961-1975 (Toronto: University of Toronto Press, 2006).

23 B.(R.) v. Children's Aid Society of Metropolitan Toronto, [1995] 1 S.C.R. 315 (CanLII). The case concerned devout Jehovah's Witness parents who refused to consent to a blood transfusion for their infant. When the Children's Aid Society secured a court order of temporary guardianship so the transfusion could be performed, the parents challenged the order on the grounds that it violated their and their child's religious freedom.

24 Young v. Young, [1993] 4 S.C.R. 3 (CanLII) and P.(D.) v. S. (C.), [1993] 4 S.C.R. 141 (CanLII). The issue in these cases was court-ordered custody arrangements which prevented the non-custodial parent (the father) from disparaging the mother's (Roman Catholic) faith or taking the children soliciting in public (such as door-to-door, a required part of mission work for Jehovah's Witnesses); in both cases, the marriages had broken down largely because of religious discord. John Stuart Mill, On Liberty and Considerations on Representative Government, ed. by R. B. McCallum (Oxford: Basil Blackwell, 1946).

26 Respectively, Angela Campbell et. al, Polygamy in Canada: Legal and Social Implications for Women and Children - A Collection of Policy Research Reports (Ottawa: Status of Women Canada, 2005), online: < http://www.swc-cfc.gc.ca/ pubs/pubspr/0662420683/200511_0662420683_ e.pdf $>$ [Polygamy] and Rebecca J. Cook \& Lisa M. Kelly, Polygyny and Canada's Obligations under International Human Rights Law (Ottawa: Department of Justice Canada, 2006), online: <http://www.justice.gc.ca/en/dept/pub/poly/poly. pdf $>$ [Cook and Kelly].

27 R. v. Butler, [1992] 1 S.C.R. 452 (CanLII).

28 R. v. Labaye, 2005 SCC 80, [2005] 3 S.C.R. 728 (CanLII).

29 Malmo-Levine, supra note 20 at paras. 77 and 117-19.

30 Alberta Civil Liberties Research Centre, "Separate and Unequal: The Women and Children of Polygamy" in Polygamy, supra note 26 at 25-26.

31 Cook and Kelly, supra note 26 at 22.

32 R. v. F. (R.P.), [1996] 105 C.C.C. (3d) 435.

33 Ford v. Quebec (Attorney General), [1988] 2 S.C.R. 
712 (CanLII), where the Supreme Court voided Quebec's total ban on non-French outdoor commercial signage, but concluded that the "marked predominance" of French on such signs would meet Quebec's objective of promoting and protecting the province's French language and culture.

34 RJR-MacDonald Inc. v. Canada (Attorney General), [1995] 3 S.C.R. 199 (CanLII), in which the Supreme Court vitiated the federal government's complete ban on tobacco advertising in favour of a narrower ban on "lifestyle advertising."

35 Halpern, supra note 1 at para. 139.

36 Martha Bailey, Beverley Baines, Bita Amani, and Amy Kaufman, "Expanding Recognition of Foreign Polygamous Marriages: Policy Implications for Canada" in Polygamy, supra note 26 at 29.

37 Blencoe v. British Columbia (Human Rights Commission), 2000 SCC 144 [2000] 2 S.C.R. 307 (CanLII) at para. 54.

38 Bailey et al., supra note 36 at 30.

39 Krieger v. Law Society of Alberta, 2002 SCC 65, [2002] 3 S.C.R. 372 (CanLII). See also Lori Sterling \& Heather Mackay, "Constitutional recognition of the role of the Attorney General in criminal prosecutions: Krieger v. Law Society of Alberta" (2003) 20 Supreme Court Law Review (2d) 169. 